\title{
LIPOXYGENASE INHIBITORY ASSAY OF ETHYL ACETATE FRACTION FROM STAR FRUIT LEAVES (AVERRHOA CARAMBOLA L.) FROM THREE REGIONS IN WEST JAVA
}

\author{
DEFI SUCIANA SUBARDINI, BERNA ELYA*, ARIKADIA NOVIANI
}

Faculty of Pharmacy, Universitas Indonesia, Depok 16424, Indonesia. Email: berna.elya@farmasi.ui.ac.id

Received: 20 September 2019, Revised and Accepted: 06 December 2019

ABSTRACT

Objective: Averrhoa carambola L. leaves have been used as a traditional medicine. The study aimed to examine the anti-inflammatory activity of A. carambola L. plant extracts using a lipoxygenase inhibition assay based on ethyl acetate fractions of $A$. carambola L. leaves obtained from three regions in West Java.

Methods: Extracts from A. carambola L. leaves were obtained by maceration method using $70 \%$ ethanol followed by fractionation using liquid-liquid partitioning until the ethyl acetate fraction was obtained. Subsequently, lipoxygenase inhibition activity of the ethyl acetate fraction was tested using

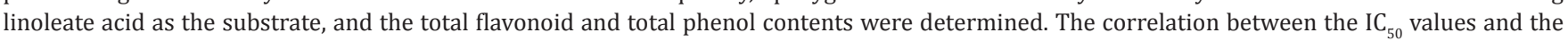
total flavonoid and total phenol contents obtained from the ethyl acetate fraction were analyzed.

Results: The ethyl acetate fraction from the sample inhibited lipoxygenase enzyme activity with IC ${ }_{50}$ values of $19.38,16.65$, and $15.07 \mu \mathrm{g} / \mathrm{mL}$, respectively. The total flavonoid contents in the ethyl acetate fractions obtained from Depok, Subang, and Sukabumi regions were 14.88, 16.88, and 22.27 mg QE/g of sample, respectively, whereas the total phenol contents were 54.10, 61.06, and $72.18 \mathrm{mg}$ gallic acid equivalents/g of sample, respectively.

Conclusion: There was a high correlation between the $\mathrm{IC}_{50}$ values and the total flavonoid and total phenol contents, with correlations coefficients of -0.917 and -0.960 , respectively, which indicated that the higher the total flavonoid and total phenol contents, the lower the $\mathrm{IC}_{50} \mathrm{values}$

Keywords: Averrhoa carambola L., Inflammation, Lipoxygenase, Determination of flavonoid content, Determination of phenol content.

(C) 2020 The Authors. Published by Innovare Academic Sciences Pvt Ltd. This is an open access article under the CC BY license (http://creativecommons. org/licenses/by/4. 0/) DOI: http://dx.doi.org/10.22159/ijap.2020.v12s1.FF025

\section{INTRODUCTION}

Star fruit (Averrhoa carambola L.) leaves are used as traditional medicines for the treatment of inflammatory skin disorders such as eczema, boils, and pyoderma or skin infections caused by bacteria, viruses (smallpox), or fungi (ringworm) [1-3]. Lipoxygenase is an enzyme that is involved in the biosynthesis of inflammatory mediators such as leukotrienes, which plays an important role in the pathogenesis of inflammatory diseases such as asthma [4-6]. Natural chemicals in the form of flavonoids in A. carambola plants, particularly flavones, exhibit potential anti-inflammatory activity [7]. The previous studies have reported an $\mathrm{IC}_{50}$ inhibition value of apigenin against lipoxygenase activity of $2.08 \mathrm{ppm}$ and an $\mathrm{IC}_{50}$ value of $7.84 \mathrm{ppm}$ from the star fruit ethyl acetate fraction; therefore, it was considered to prevent skin edema and has been used in cosmetic preparations as a skin-soothing agent [8]. The aim of the present study was to obtain data on lipoxygenase inhibition activity of the ethyl acetate fraction of A. carambola L. leaves from three regions in West Java (Depok, Subang, and Sukabumi) and to examine the correlation between the total flavonoid and total phenol contents based on $\mathrm{IC}_{50}$ values.

\section{MATERIALS AND METHODS}

\section{Chemicals and materials}

A. carambola L. leaves were obtained from three regions in West Java (Depok, Subang, and Sukabumi). All other chemical and reagents were commercially sourced, including 5-lipoxygenase from soybean (SigmaAldrich-L7395-15MU, USA), linoleic acid (Sigma-Aldrich-L2376, USA), methanol, n-hexane, ethanol, ethyl acetate, sodium hydroxide, boric acid, and potassium chloride (Merck, Germany), aqua distilled (Brataco, Indonesia), aqua demineralization (Brataco, Indonesia), sodium acetate (Brataco, Indonesia), and Folin-Ciocalteu concentrated solution reagent (Merck, Germany). Apigenin (Sigma-Aldrich-01760595-10MG) was used as the standard in the inhibition test of lipoxygenase activity, whereas quercetin (Sigma-Aldrich-Q4951, USA) and gallic acid (SigmaAldrich, USA) were used for the determination of total flavonoid and total phenol contents, respectively.

\section{Preparation of $A$. carambola leaf extracts}

A. carambola leaves from three regions in West Java were collected in December 2017; they were identified by the Center for Plant Conservation of Indonesian Institute of Sciences (LIPI), Bogor, West Java, Indonesia.

\section{Extraction and fractionation}

Dried powdered leaves (700 g) were extracted using the maceration method with $70 \%$ ethanol at room temperature for 1 day and then the solvent was evaporated using a rotary vacuum evaporator and a water bath $\left(50^{\circ} \mathrm{C}\right)$. Ethanol extracts were fractionated using the liquidliquid partition method with n-hexane, ethyl acetate, and water as the solvents. The ethyl acetate fraction was reconcentrated using a rotary vacuum evaporator $(100 \mathrm{rpm})$ at $40^{\circ} \mathrm{C}$ [8].

\section{Lipoxygenase activity inhibitor test}

Enzyme activity was measured using an ultraviolet-visible (UV-Vis) spectrophotometer at $234 \mathrm{~nm}$ and $25^{\circ} \mathrm{C}$ with apigenin as a positive control. The lipoxygenase assay was performed by reacting $50 \mu \mathrm{l}$ of the ethyl acetate fraction sample solution of five different concentrations with apigenin as a positive control, $1690 \mu \mathrm{l}$ of $0.2 \mathrm{M}$ borate buffer ( $\mathrm{pH}$ 9), $1000 \mu \mathrm{l}$ of $900 \mu \mathrm{M}$ linoleic acid substrate (Sigma-Aldrich), and then incubated for $10 \mathrm{~min}$ at $25^{\circ} \mathrm{C}$. Subsequently, $300 \mu \mathrm{L}$ of $300 \mathrm{U} / \mathrm{mL}$ lipoxygenase solution was added and the mixture incubated for $15 \mathrm{~min}$ at $25^{\circ} \mathrm{C}$. The enzyme reaction was terminated by adding $1 \mathrm{~mL}$ methanol to obtain a final volume of $4 \mathrm{~mL}$ and absorbance of product is an hydroperoxy-octadecadienoic acid reaction [8]. 
The inhibition of lipoxygenase activity was calculated using the following equation:

$$
\% \text { lipoxygenase inhibition }=\frac{(\mathrm{A}-\mathrm{B})-(\mathrm{C}-\mathrm{D})}{(\mathrm{A}-\mathrm{B})} \times 100 \%
$$

$A=$ Absorbance of reference solution with enzyme

$\mathrm{B}=$ Absorbance of reference solution without enzyme

$\mathrm{C}=$ Absorbance of standard or sample solution with enzyme

$\mathrm{D}=$ Absorbance of standard or sample solution without enzyme.

\section{Determination of total flavonoid content}

The total flavonoid content was determined using a UV-Vis spectrophotometer at $430 \mathrm{~nm}$ with quercetin used as the standard and to plot the calibration curve. The total flavonoid content was reported as total quercetin equivalent per g of extract (mg QE/g extract). For the test, take $0.5 \mathrm{~mL}$ sample test solution or the standard was mixed with $1.5 \mathrm{~mL}$ ethanol concentrated solution, $0.1 \mathrm{~mL}$ of $10 \% \mathrm{AlCl}_{3}$ solution, $0.1 \mathrm{~mL}$ of $1 \mathrm{M}$ sodium acetate solution, and $2.8 \mathrm{~mL}$ distilled water. After incubation at room temperature for $30 \mathrm{~min}$, the absorbance of the reaction mixture was measured at $430 \mathrm{~nm}$ [9].

\section{Determination of total phenol content}

The total phenol content was determined using a UV-Vis spectrophotometer at $730 \mathrm{~nm}$ and gallic acid was used as the standard and to plot the calibration curve. The total phenol content was reported as total gallic acid equivalent per g extract (mg gallic acid equivalents [GAE]/g extract). For the test, $1 \mathrm{~mL}$ standard or sample solution was mixed with $5 \mathrm{~mL}$ of $7.5 \%$ Folin-Ciocalteu reagent LP, incubated for $8 \mathrm{~min}$ and $4 \mathrm{~mL}$ of $1 \% \mathrm{NaOH}$ added followed by incubation for $1 \mathrm{~h}$. The absorbance of the reaction mixtures was measured at $730 \mathrm{~nm}$ [10].

\section{Statistical analysis}

Statistical analyses were conducted to determine the $\mathrm{IC}_{50}$ values with the total flavonoid and phenol contents in the ethyl acetate fraction of the leaves obtained from the three regions. The analyses were performed using IBM SPSS Statistics 22 (IBM Corp, Armonk, NY, US). First, the data were tested for normality and then a correlation test was performed. The results of the normality test facilitated the determination of the appropriate correlation test.

\section{RESULTS}

\section{Extraction and fractionation}

Extraction is a method for separating the active compound from the plant using a selective solvent. Extracts of $A$. carambola leaves were obtained using the maceration method. The yields obtained from $700 \mathrm{~g}$ leaf samples were $225.55 \mathrm{~g}(32.33 \%)$ from the Depok samples, $246.59 \mathrm{~g}(35.22 \%)$ from the Subang samples, and $165.79 \mathrm{~g}(23.68 \%)$ from the Sukabumi samples. Fractionation is a method of separating the components of a sample based on their solubility. Based on the results of obtained fraction, the highest amount of the ethyl acetate fraction was observed in A. carambola leaves from Subang (15.24 g [6.18\%]) followed by Depok at $16.83(4.19 \%)$ and the lowest amount observed was $6.3 \mathrm{~g}$ from Sukabumi (3.79\%).

\section{Lipoxygenase activity inhibition}

The inhibition of lipoxygenase activity by the ethyl acetate fractions of the leaves obtained from the three study regions in West Java with linoleate acid as the substrate was compared using standard apigenin. The apigenin $\mathrm{IC}_{50}$, used as the positive control, was $2.03 \mathrm{ppm}$, whereas the $\mathrm{IC}_{50}$ of the ethyl acetate fractions of leaf samples from Depok, Subang, and Sukabumi was 19.38, 16.65, and 15.07 ppm, respectively.

\section{Total flavonoid contents}

Based on the standard quercetin calculation curve, there was a linear correlation between absorbance and concentration, with the following linear regression equation: $y=0.0829 x+0.0067(r=0.9994)$. The equation was used to estimate the total flavonoid content in the extracts. The total flavonoid contents in the ethyl acetate fraction of the leaf samples from Depok, Subang, and Sukabumi were 14.875,
16.884, and $22.276 \mathrm{mg} \mathrm{QE}$, respectively, with pure quercetin used as the standard.

\section{Total phenol contents}

Based on the standard gallic acid calculation curve, there was a linear correlation between absorbance and concentration, with the following linear regression equation: $y=0.1998 x+0.0425(r=0.9981)$. The equation was used to estimate the total phenol contents in the extracts. The total phenol contents in the ethyl acetate fraction of the leaf samples from Depok, Subang, and Sukabumi were 54.102, 61.066, and $72.180 \mathrm{mg}$ GAE with pure gallic acid used as the standard.

\section{Statistical analysis}

The results of the correlation test between $\mathrm{IC}_{50}$ values and flavonoid content yielded a correlation coefficient with a value of -0.917 , whereas that of the test between $\mathrm{IC}_{50}$ values and phenol content yielded a value of -0.960 .

\section{DISCUSSION}

\section{Extraction and fractionation}

Extraction using the maceration method with $70 \%$ ethanol at room temperature could minimize challenges associated with metabolic processes and the degradation of metabolites. About $70 \%$ ethanol was selected because it provided higher yield extracts from A. carambola $\mathrm{L}$. leaves [8]. The extraction of each solvent is performed thrice to maximize yield [11]. Using solvents with different polarities could facilitate the extraction of chemical compounds based on their polarity, for example, semi-polar compounds such as isoflavones, flavones, and flavonols are extracted using ethyl acetate solvents, and it can be used to inhibit lipoxygenase activity. The highest ethyl acetate fraction yield was obtained from A. carambola L. leaves from Subang followed by Depok and Sukabumi.

\section{Lipoxygenase activity inhibition}

Based on the results, the ethyl acetate fraction obtained from A. carambola L. leaves of the Sukabumi region exhibited the highest lipoxygenase inhibition activity with an $\mathrm{IC}_{50}$ value of $15.07 \mathrm{ppm}$ followed by those from the Subang and Depok regions with $\mathrm{IC}_{50}$ values of $16.65 \mathrm{ppm}$ and $19.38 \mathrm{ppm}$, respectively. Based on the previous study, the $\mathrm{IC}_{50}$ value of the ethyl acetate fraction of $A$. carambola leaves from Depok was $7.84 \mathrm{ppm}$ [8]; however, in the present study, which collected numerous samples, the $\mathrm{IC}_{50}$ value was $19.38 \mathrm{ppm}$. We concluded that the regions did not influence the lipoxygenase inhibition activity; however, other factors such as time of harvesting of the tree could have influenced the activity.

\section{Total flavonoid content}

The total flavonoid assay was performed using the $\mathrm{AlCl}_{3}$ colorimetric method with quercetin as a positive control. $\mathrm{AlCl}_{3}$ can form a stable complex with the $\mathrm{C}_{4}$-keto group and a hydroxyl group at $\mathrm{C}_{3}$ and $\mathrm{C}_{5}$ of flavones and flavonols. In addition, $\mathrm{AlCl}_{3}$ can form labile complexes with ortho-dihydroxyl groups in ring A and B flavonoids [9]. Flavonoids present in an extract may contribute to the inhibition of lipoxygenase activity. Based on the results, the highest total flavonoid content was noted in the ethyl acetate fractions obtained from A. carambola L. leaves of the Sukabumi region followed by those of the Subang and Depok regions.

\section{Determination of total phenol content}

Determination of the total phenol content was performed by a colorimetric method using standard gallic acid and Folin-Ciocalteu reagent, which relies on the transfer of electrons in the alkaline medium from phenol compounds to phosphomolybdic-phosphotungstic complexes [10]. According to the results, the highest total phenol content in the ethyl acetate fraction was observed in A. carambola leaves of the Sukabumi region followed by those of the Subang and Depok regions.

\section{Statistical analysis}

The purpose of a correlation test is to determine the correlation level between the variables stated based on a correlation coefficient 
(r). Total flavonoid and phenol contents were highly correlated and inversely proportional to the $\mathrm{IC}_{50}$ values of the extracts of the leaves from three regions, with correlation coefficients of -0.917 and -0.960 , respectively, which indicate that the higher the total flavonoid and total phenol contents, the lower the $\mathrm{IC}_{50}$ values.

\section{CONCLUSION}

The total flavonoid contents and $\mathrm{IC}_{50}$ values of the extracts of the leaves from the three regions were highly correlated and inversely proportional, with a correlation coefficient of -0.917 . In addition, the total phenol contents in the ethyl acetate fraction from the regions sampled, including Depok, Subang, and Sukabumi, were highly correlated and inversely proportional to the $\mathrm{IC}_{50}$ values, with a correlation coefficient of -0.960 . According to the results, the higher the total flavonoid and total phenol contents, the lower the $\mathrm{IC}_{50}$ values.

\section{ACKNOWLEDGMENTS}

The authors are thankful to Universitas Indonesia who had given financial support for this research.

\section{CONFLICTS OF INTEREST}

The authors declare no conflicts of interest.

\section{REFERENCES}

1. Dasgupta P, Chakraborty P, Bala NN. Averrhoa carambola: An update review. Int J Pharm Res Rev 2015;2:58.
2. Khanam Z, Sam KH, Hazerra N, Ching CH, Bhat IU. Determination of polyphenolic content, HPLC analyses and DNA cleavage activity of Malaysian Averrhoa carambola L. fruit extracts. J King Saud Univ Sci 2015;27:331-7.

3. Moresco HH, Queiroz GS, Pizzolatti MG, Brighente IM. Chemical constituents and evaluation of the toxic and antioxidant activities of Averrhoa carambola leaves. Rev Bras Farmacog 2012;22:319-24.

4. Murray RK, Granner DK, Rodwell VW. Harper's Biochemical. $27^{\text {th }}$ ed. Jakarta: Buku Kedokteran EGC; 2009.

5. Avelia S, Mauldina MG, Elya B. Antioxidant activity and lipoxygenase inhibitory assay with total flavonoid content of Garcinia lateriflora blume leaves extract. Asian J Pharm Clin Res 2017;10:163-5.

6. Elya B, Puspitasari N, Sudarmin AC. Antioxidant activity and inhibition of lipoxygenase activity ethanol extract of endosperm Arenga pinnata (wurmb) merr. Asian J Pharm Clin Res 2017;10:76-80.

7. Thomas S, Patil D, Patil AG, Chandra N. Pharmacognostic evaluation and physicochemical analysis of Averrhoa carambola L. fruit. J Herb Med Toxicol 2008;2:51-4.

8. Nabilah, Elya B, Djajadisastra J. Lipoxygenase inhibitory assay of Averrhoa carambola L. leaves extract. Int J ChemTech Res 2017;10:342-7.

9. Chang C, Yang M, Wen H, Chern J. Estimation of total flavonoid content in propolis by two complementary colorimetric method. J Food Drug Anal 2002;10:178-82.

10. Ainsworth EA, Gillespie KM. Estimation of total phenolic content and other oxidation substrates in plant tissues using Folin-Ciocalteu reagent. Nat Protoc 2007;2:875-7.

11. Ministry of Health of the Republic of Indonesia. Supplements II, Indonesian Herbal Pharmacopoeia. Jakarta: Ministry of Health of the Republic of Indonesia; 2011. 